\title{
A Pathological Anatomical Study of Crystal Cyst Formation in Parenchymatous Tissue in the Genus Anthurium.
}

\author{
LIBRARY \\ BY \\ J. A. SAMUELS. \\ NEW YORK \\ BOTANKAL \\ GARDEN
}

With Plate II and five Figures in the Text.

I. INTRODUCTION.

T $\mathrm{P}$ to the present time, cell and nuclear fusions in somatic cells have been regarded from an anatomical standpoint as independent phenomena. A recent study of the processes in Anthurium scandens, however, has afforded the writer an opportunity to observe a relation between them which complicates the theoretical conceptions of the subject (46).

It is well known that in the last decades many investigators have added greatly to our knowledge of nuclear and protoplasm fusions in vegetative cells, and that their investigations have led to interesting conclusions. One need only mention the multiple nuclear fusions in the endosperm of many Angiosperms (7), the fusions of the tapetal nuclei in the anthers of certain plants $(55,58,63)$, the fusions of certain cells in the ovule of Tropaeolum (63), the multinucleate cells in the procambium and the plerome of certain plants, and the formation of a symplast after infection by Synchytrium and some Heteroderas $(25,37)$.

It would appear that, in vegetative tissue, most of these cases of cell and nuclear fusions are generally due directly to the influence of the high acidity of the cell or to a certain cell complex. The direct cause, however, may be of a different nature; for example, abnormal physiological conditions.

None of the cases at present known in which the acidity affects a certain part of the tissue are so pronounced as is Anthurium, where large cell complexes dissolve, i. e. cell fusion takes place with the formation of a symplast and the appearance of a certain number of raphid crystal colonies.

The fusion of two neighbouring cells representing the origin of crystal cysts in young tissue cannot be discovered without difficulty. The present publication may therefore serve to illustrate such a case in Anthurium scandens and $A$. Scherzerianum.

[Annals of Botany, Vol. XXXVII. No. CXLVI. April, 1923.] 
The first part of the publication will deal only with actual observations, while in the second part an effort will be made to discuss the different phenomena regarding the presence of several nuclei in a single cell, the cell fusions, the nuclear fusions, the formation of the crystal colonies, and, finally, the end of living conditions in such hypertrophied cells.

\section{Technique.}

The material for the investigation was collected in the Botanical Garden, Paris. A portion was fixed in a solution of chromo-acetic acid and another portion in 96 per cent. alcohol. It has been found that better results could be obtained from the material treated with alcohol. Furthermore, it may be stated that the best results were secured with sections stained by Heidenhain's haematoxylin. Triple staining, according to Flemming, has also been applied with good results for the early stages, but not so successfully with the later stages.

Young leaves are better for the study of cell and nuclear fusion than leaves advanced in growth.

After the use of the Heidenhain method of staining, where the sections were left in a solution of ferric ammonium sulphate during the night, the raphid needles were dissolved so that thereafter the crystals themselves could not be seen even with the polarization apparatus. There remained but an empty space bounded by the plasma membrane which surrounded the needles. The crystals in the cells of sections stained by the triple staining method of Flemming, however, remained intact.

The sections were cut 12 microns thick and the figures were made with the Abbe drawing apparatus.

\section{The Formation of a Cyst.}

The cysts were first observed and most thoroughly studied in the perianth of Anthurium scandens and A. Scherzerianum. Later they were found also in other floral organs, in the stems and roots, and the embryo of both specimens.

The development of the cysts is indicated by the increase of the protoplasm masses and the enlargement of the nuclei of two neighbouring cells. For the time being an attempt to examine this process microscopically has yielded no results.

The cause of the hypertrophy of one of the two isolated cells can probably be attributed to physico-chemical causes, because large cell complexes in the parenchymatous tissue mentioned above are involved. Since the parenchymatous cells of a given region are anatomically and functionally similar, we would perhaps again attribute such a phenomenon to bacterial origin, but thus far no bacteria could be discovered in the cells. 
The difficulty of observing bacteria in cells filled with a dense mass of protoplasm is well known to histologists. Since the investigations on this subject are not yet concluded, at present no final judgement may be given.

In the further development of the cysts the nuclei of the two cells assume positions on opposite sides of the common cell wall. Later the wall is ruptured and a fusion or mingling of the cell contents and the nuclei occurs. P1. II, Fig. I, shows the large cell which probably arose by the fusion of two other ceils and which lies in the centre of the parenchymatous tissue. The hypertrophied cell thus produced is about twice as large as the neighbouring cells. The protoplasm containing numerous small and large vacuoles is strikingly dense and displays an embryonic character. The nucleus gives the impression of having recently arisen by the fusion of two other nuclei.

The nuclei of the neighbouring parenchymatous cells generally are not far distant from the hypertrophied nucleus. P1. II, Fig. I, shows the nucleus of the cyst lying in one corner of the enlarged cell, while the nuclei of the neighbouring cells lie near the cell walls in the immediate vicinity of the large nucleus. The fusion nucleus may or may not retain its normal spherical form. In some cases a further fusion of cells with the cyst takes place and their nuclei fuse with that of the cyst. In other cases the nucleus of the cyst becomes deformed and may assume a spiral shape. This phenomenon usually occurs in old organs. In immature organs a further fusion of the cyst with the surrounding cells takes place. Pl. II, Figs. 2, 5, II, and Text-figs. I, 3, 4, and 5, show fusions or pairing of nuclei. In Pl. II, Figs. 3 and 4 , both nuclei lie within the plasma ring that was formed by the union of the two cells.

Further enlargement of the cyst at the expense of the neighbouring cells causes a breaking down of the common cell wall and the dissolving of the remnants. This process results in the formation of a large symplast. Pl. II, Figs. 8, II, and Text-figs. I and 3, show clearly how the walls are pierced and the cell nuclei are enabled to fuse with the principal nucleus. Fragments of cell walls undergoing solution are plainly visible.

It happens very often that two young neighbouring symplasts fuse together. Text-fig. I demonstrates such a case which was observed in the third cell row from the epidermis in the perianth of Anthurium Scherzerianum. In one part of this fused cyst we find some nuclei in the act of fusing, while the nucleus of the other part has more or less an elongated form, without, however, any crystal formation in that particular part. The nuclei of the surrounding parenchyma cells maintain their round form. Within the cell, during the process of cell fusion, the protoplasm layer of the cyst is increased in thickness and an extensive crystallization of calcium oxalate takes place.

The first colony of raphids is formed in the immediate vicinity of the 
nucleus, which is embedded in an unusually large mass of protoplasm to which it is connected by means of protoplasmic strands. See Pl. II, Figs. 5, 7 ,

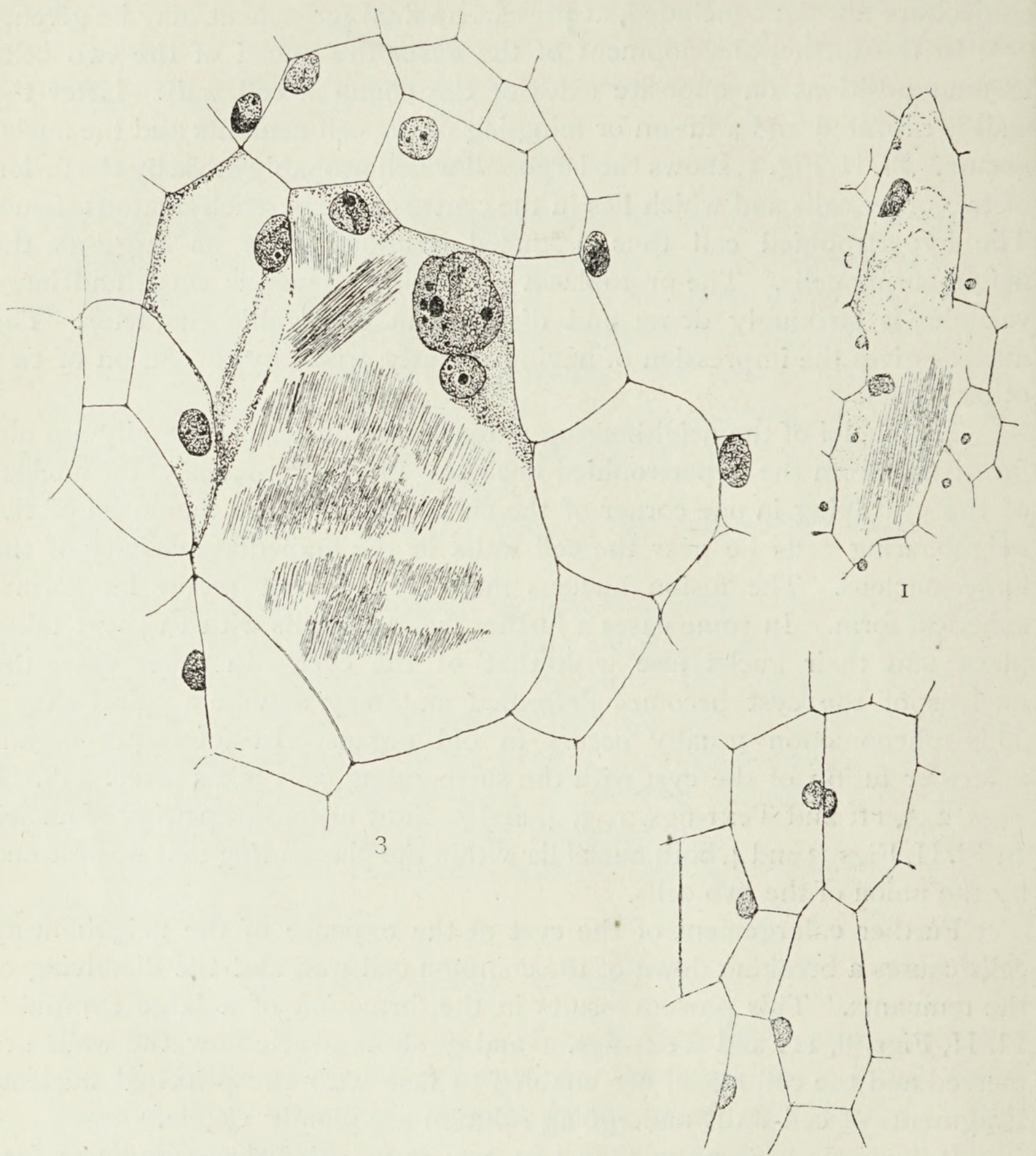

2

TEXT-FIG. I. Fusion of the two cyst cells and neighbouring cells in the parenchymatous issue of a perianth leaf of Anthurium Scherzerianum, third cell row from the epidermis. The two large cyst nuclei can be distinguished from one another. Formation of a crystal colony in one of the cysts. Obj. 4, ocular 4.

TEXT-FIG. 2. The section following that of Text-fig. I, showing the nuclei lying against the cell wall. Oil immersion, ocular 2.

TEXT-FIG. 3. Large cyst cell from the parenchymatous tissue of the perianth leaf of Anthurium Scherzerianum, demonstrating the large cyst nucleus after the fusion of a number of nuclei. Another nucleus of a neighbouring cell, united, and ready to fuse with the main nucleus. Fusion of the main symplast cell with other neighbouring cells. Many crystal colonies formed in different directions. Nuclei of the neighbouring cells lying more or less against the cell wall. Some of these nuclei becoming homogeneous. Oil immersion, ocular 4 .

and II. If the cyst is conspicuously elongated the nucleus is usually situated at one end of the cell. After the formation of the first raphid colony, others 


\section{Crystal Cyst Formation in Parenchymatous Tissue. ${ }_{1} 63$}

are formed with the component needles either parallel to the first or pointing in various directions (Pl. II, Figs. 8 and II ; Text-fig. 3 ).

The position of the groups of crystals indicates clearly that masses of oxalate move in various directions within the cell. This fact shows that various abnormal processes occur. It could not be determined whether the number of raphid colonies correspond to the number of fused nuclei or not. The crystals do not lie within the vacuole, as is usually the case $(20,42,59)$,

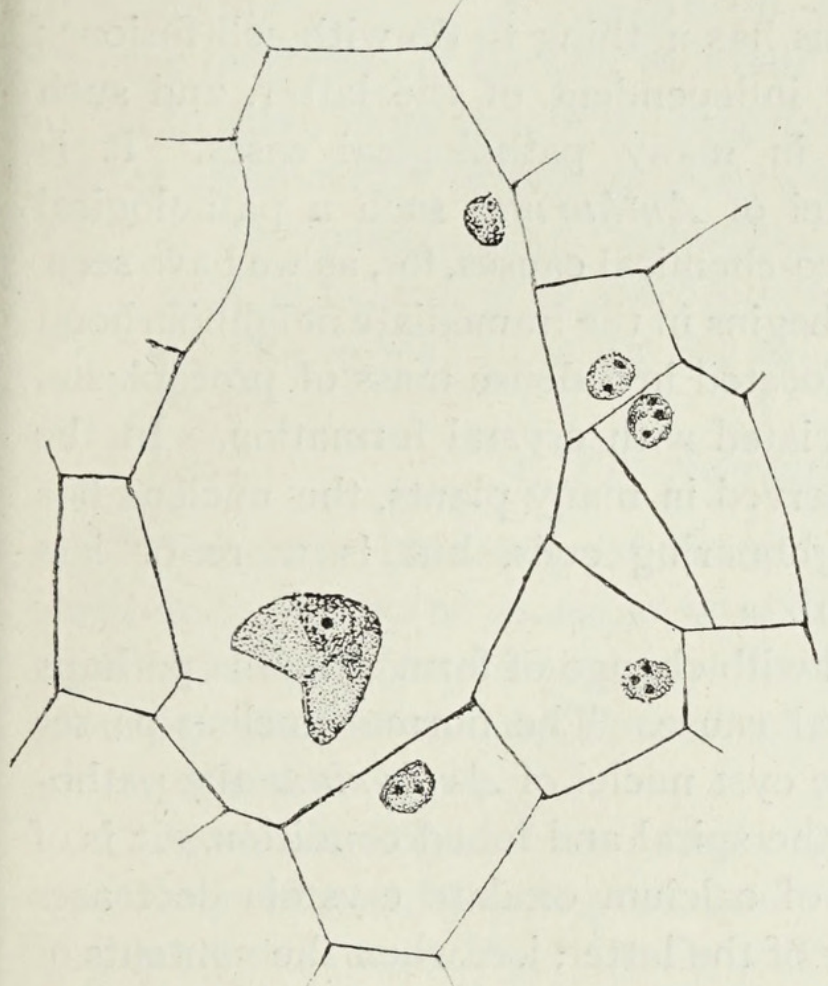

4

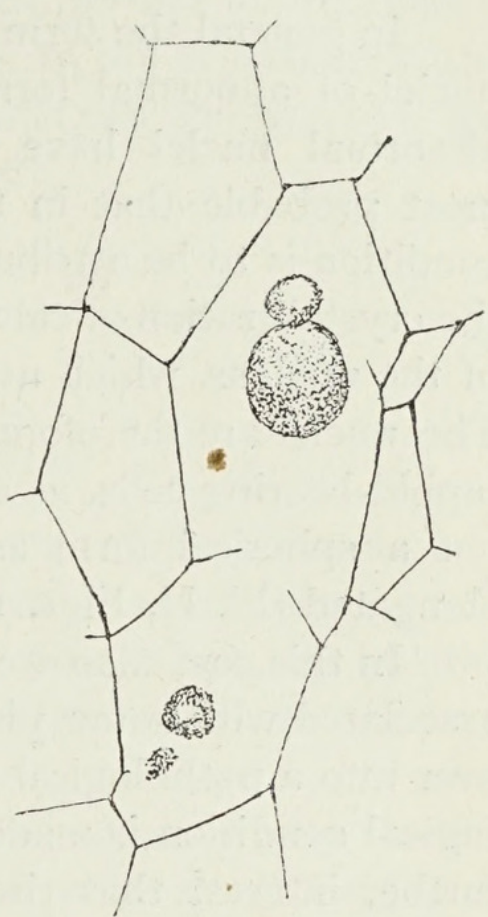

TEXT-FIG. 4. Part of the tissue of a perianth leaf of Anthurium Scherzerianum, third cell row from the epidermis. Fusion of a large cyst cell with a neighbouring cell. Fusion of the cyst nucleus with the nucleus of the latter. At the other end of the cyst another nucleus ready to unite with the large cyst nucleus. Nuclei of the neighbouring cells with a normal form showing a tendency of lying along the cell wall. Oil immersion, ocular 8.

TEXT-FIG. 5. Fusion of four cells to a large symplast in the parenchymatous tissue of the perianth leaf of Anthurium Scherzeriamum. Union of the nuclei of the upper two cells. The nucleus of the third and a piece of that of the fourth cell can be seen at the other pole of the young cyst cell. Oil immersion, ocular 7 .

but rather in the protoplasm. Sometimes a single colony occupies the entire width of the cyst (Pl. II, Figs. 6 and 7).

During the development of a large cyst the nuclei of the neighbouring cells exhibit a curious phenomenon. They become distorted and homogeneous in appearance and show a tendency to fuse. But even in those parts of the tissue where a fusion has not yet taken place, the nuclei of the cells apparently unaffected are homogeneous and are located near o1 alongside the cell wall, which therefore indicates a tendency to fusion with neighbouring cells (Text-figs. 2, 3, and 4).

During or even very shortly before the formation of crystals the 
nucleus of the cyst undergoes certain changes. It may assume lobed, spiral, or twisted forms, as shown in P1. II, Figs. I0, I2, I3, I4, and I5, and Text-figs. I, 3 , and 4 .

It is not unlikely that this amoeboid change of form is associated with chemical or physical changes in the constitution of the cell, for it is well known that nuclei can be stimulated by physical or chemical means so as to undergo pathological fusion, and this I believe is the case in Anthurium.

In general the form of the nucleus has nothing to do with cell fusions ; nuclei of abnormal form may occur independent of the latter, and such abnormal nuclei have been found in many pathological cases. It is most probable that in the cyst nuclei of Anthurium such a pathological condition is to be attributed to physico-chemical causes, for, as we have seen, the crystallization of calcium oxalate begins in the immediate neighbourhood of the nucleus, which at the time is located in a dense mass of protoplasm. The nuclei are therefore closely associated with crystal formation. In the raphid-bearing cells, as ordinarily observed in many plants, the nucleus has not a spherical form as in the neighbouring cells, but is more or less elongated (Pl. II, Figs. I4, I5, and I6).

In this case also we have to deal with change of form which is perhaps associated with some physico-chemical cause. The normal nucleus passes over into a pathological state. In the cyst nuclei of Anthurium the pathological condition is made evident by the spiral and lobed condition. It is of further interest that the production of calcium oxalate crystals decreases with the final cessation of the activity of the latter, i. e. when the contents of the nucleus become homogeneous and are about to dissolve. From this fact it is clear that there is a relation between the cyst nucleus and crystal formation. The relation between the form of the cells and cell growth and the position and function of the nucleus can be clearly determined and followed in the case of these crystal symplasts. It may be emphasized that the formation of these peculiar symplasts, whose origin is, in all probability, to be attributed to abnormal physico-chemical processes in the tissue, takes place, not in the outer parenchyma cell layers of the perianth leaves, but for the most part in the inner layers. In the outer layers mainly polyhedric crystals are formed, and neither cell association nor nuclear fusion is to be observed.

The formation of crystal cysts may be observed not only in all the vegetative organs of Anthurium scandens and A. Scherzerianum, but also, in all probability, in other species of the genus Anthurium. ${ }^{1}$

1 The occurrence of similar crystal symplasts in the parenchymatous tissue of the floral organs of Arisaema triphyllum, which I had the opportunity to observe in the early part of this season, may also be noted here. 


\section{Discussion.}

Having described the origin of such a cyst, it may be well to compare it with the process of development of an ordinary raphid-bearing cell, particularly in view of the fact that in both cases abnormal regulatory phenomena are principally dealt with. The two kinds of crystal cells differ principally from each other in that only in the former do cell and nuclear fusions take place. A comparison will at least yield further information as to the behaviour of the cell elements with reference to the çrystal structure.

In this comparison of the origin of a simple raphid cell and that of a cyst, three prominently important points are to be noted:

I. The behaviour of the nucleus.

2. The behaviour of the protoplasm.

3. The formation of the crystal colonies.

\section{The Behaviour of the Nucleus.}

From the behaviour of the nuclei with respect to the protoplasm it will undoubtedly be possible to arrive at a conclusion as to whether the protoplasm suffers through the formation of crystals or not, or, in other words, whether or not normal physiological conditions or processes are interrupted.

Rosanoff (42) and later De la Rue (10) in Hoya carnosa were the first to observe crystal-bearing cells, and they noted the survival of the nucleus after crystal formation. De Bary (9) also mentioned briefly the survival of the nucleus of such cells which have not yet lost their vitality, i.e. whose cell contents are not yet filled with crystal substance.

In the cell, during the formation of the crystal, there arise entirely different conditions, physico-chemically and physiologically, which certainly affect the form and the position of the nucleus.

Kohl (20), who studied such raphid cells, especially in Hyacinthus orientalis, Vanilla planifolia, and Orchid bulbs, found that the nucleus, immediately after appearance of vacuoles, assumed a vertical position adjacent to the cell wall, where it remained during its cell existence (p. 274). According to Kohl the raphid bundle is always formed in the centre of the cell, and especially in the cells where a contraction of the protoplasmic wall covering has taken place. In these cases he points out that the nucleus is in direct connexion with the raphid bundle. Zacharias (65) and Johow (19) made the same observation in raphid-bearing tubes of Monocotyledons and Dicotyledons.

It was possible to determine from my observations on Anthurium, that the position and form of the nucleus in the crystal cysts are influenced by abnormal physiological processes, i. e. by the growth of the calcium oxalate 
substance within the cell. At the appearance of the vacuoles the nucleus is pushed aside. Crystal formation influences the position of the nucleus, if not directly, at least indirectly. It is a fact, however, that the position of the vacuoles depends entirely upon the physico-chemical conditions, while the position of the nucleus is a purely physical or chemical phenomenon. The nucleus of an ordinary crystal or raphid-forming cell has, for this reason, a position adjacent to the wall; in fact, along the longitudinal wall. It is very seldom seen at either of the ends. However, in the cyst cell the nucleus may frequently be observed at one end of the cell. The large hypertrophied nucleus is always in contact with the crystal or with the raphid colonies which lie in various directions, though masses of protoplasm may often be very dense and concentrated.

The nucleus in a cyst cell differs in its position from an ordinary prism or raphid cell, in that in the former there results a general physiological influence radiating towards the nucleus, equal in all directions, whereas in the ordinary prism cell the influence is exerted outward from the point on the cell wall at which the nucleus lies.

The fusion of adjacent neighbouring protoplasts with a particular protoplast creates a certain pressure upon the nuclear mass of the latter, thus causing it to assume a position which depends upon the direction of the pressure exerted by neighbouring protoplasts. The nucleus may be kept upright or forced into some other permanent position by reason of the mass of calcium oxalate crystals which develop at the centre of the cell. The change of position of the nucleus is thus the result of simple mechanical conditions.

Heidenhain (17) and his school observed that in the case of resting cells containing a great deal of granular material, the nuclei come to lie flat on the lower side of the cell. However, when secretion begins the nuclei raise themselves somewhat from the base of the cell, finally becoming bubble-like, and do not stain as heavily as before.

Nussbaum (38) and later Heidenhain (17) declare that these conditions arise from purely mechanical causes, because the nuclei in the resting cells (Driisenzellen) are mechanically influenced by the accumulation of the secreted material in the body of the cell, and make it possible therefore-on account of the accumulation of the secreted material-for the nuclei to move again into original position of equilibrium. It is doubtful whether or not the granular material in the resting cells mentioned by Heidenhain should be compared with the calcium oxalate substance discussed here. Although it is more or less certain that they are substances of different chemical constitution, it is a matter of fact that both are secreted material deposited in the cell; they both have a certain influence on the nucleus.

While it is easier to compare to a certain extent the above-mentioned 
case described by Heidenhain with conditions prevailing in the ordinary calcium oxalate crystal cell, it is very difficult to compare the behaviour of the nucleus in the former case with that of the crystal cyst. In the formation of the cyst cell an activity in different directions takes. place, i. e. a fusion of a whole cell complex occurs whereby the control of the movement or position of the nucleus in the original young cyst cell is very often lost.

Other abnormal conditions inside and outside the original cyst are added, i. e. the accumulation of the secreted material in the cell body, which is of course pronounced in the fusion with neighbouring cells; the study of the behaviour of the nucleus is thus much more difficult. Under these circumstances an additional and essential factor should be kept in view, which is certainly of some importance in regard to the behaviour of the nucleus in the cases of function of crystal substances in cells, generally speaking.

In the crystal cell there is an accumulation of secretion material which is evidenced by the crystallization of the oxalate substance by which water molecules are stored. The protoplasm is consequently deprived of molecules of water. Finally, the nucleus is also influenced by the withdrawal of water from the protoplasm, whereby the regulatory phenomena are disturbed.

There also can be no doubt that the stimulus, be it an external or an internal one, first affects the protoplasm and then directly or eventually the nucleus. However, the irritation may influence only the plasma or both it and the nucleus. This of course depends entirely upon the quality and the quantity of the stimulus. The changes in form of the nucleus are therefore brought about indirectly and do not result from the direct effects of the irritation.

Fuchs (13) found in the raphid cells of Galium Mollugo, Asperula tinctoria, and also of Hydrangea Hortensia and Aloe, that the nucleus in the crystal cell is of an elongated and more or less spindle-like form, whereas the nucleus in Mesembryanthemum crystallinum was round and entirely indistinguishable from the nuclei of other cells. It may be that in the latter case the nucleus was only temporarily round, and had not yet been influenced by the irritation or would not be influenced at all. From the work of Fuchs it does not appear whether or not the nucleus keeps its round form or whether it changes in form later.

As far as can be ascertained, no one has undertaken to systematically observe the behaviour of the nucleus during the development of such crystal cells. In any event, the observations of Fuchs are not sufficient to lead to any definite conclusion.

The temporary spherical form of the nuclei of the crystal cysts in Anthurium offers an interesting example of changes of form under the influence of irritation stimuli. After the fusion of the nucleus of the 
neighbouring cell with the nucleus of the young cyst, the nucleus of the latter displays a more or less round form. Later, it stretches lengthwise and takes a position along the wall, and indeed, most frequently, at one of the ends of the hypertrophied cell. Because of the abnormal regulatory processes in this condition of cyst development, the nucleus is pushed to one side.

The fusion of the protoplasts reminds one of the normal fusion of living protoplasts or of the ontogeny of non-septated (36) and septated sieve tubes, and also of the processes of the sexual cell fusions. This is likewise true of normal fusion processes, found for example in the pith of the hypocotyl and epicotyl of the bean stem which has been treated with violet or diffused light, ${ }^{1}$ and also of the cell fusion during the formation of secretorial cysts and tubes. Cell fusion may finally take place after infection, as for example in the case of Heterodera Schachtii (25). Küster suggests that it is very difficult to decide whether the material which dissolves the cell wall is produced by the parasite or by the host cells themselves. In the crystal symplasts there occurs a similar solution of perforated or defective cell walls. The cell-wall dissolving material is after all probably produced in this case in the symplasts themselves. It is certainly more difficult to find the reason for the fusion of two parenchymatous cells with a young cyst cell, than to determine the cause of the fusion of two or more endosperm cells. Since it might be suggested that, in the latter case, there is a solution which is of enzymic nature and concerns the solution of reserve products, it is a matter of fact that, by the fusion of nuclei of other neighbouring cells with this hypertrophied nucleus, the latter becomes richer in water, and for that reason assumes its original form again.

However, if the fusion ceases and the formation becomes more active, the combination with water begins again and also becomes more and more active; the nucleus, as a consequence, undergoes an elongation during which it takes various amoeboid and convoluted forms. Probably the increase in surface area of the nucleus enables it to absorb water molecules more freely at the proper time, so that it regains its original form. A circumstance in favour of this view is the fact that as a cell becomes older and approaches the end of its functional ability it becomes more devoid of water than before, particularly in cells of a secreting character such as those here discussed. In addition to the above suppositions relative to the withdrawal of water, other circumstances and factors may affect the change in form of the nucleus: The change in nuclear form in the calcium oxalate cyst reminds one of the change in nuclear form in the

1 Paper read at the meeting of the American Association for Advancement of Sciences in New York, I9I6. 
living leucocyte during its movements through the various connective tissues.

In the last case, according to Heidenhain; the change of form is effected by intermittent pressure exerted in rapid succession by the plasma body. Intermittently this causes considerable surface enlargement and surface changes which can only be explained by a high degree of elasticity and pliability in the nuclear membrane. It is entirely probable that in the case of crystal cysts there is a rapid successive exertion of pressure due to the tendency which exists in the young cells to unite with adjacent cells, and due also to the same tendency towards union of the nuclei.

A union or fusion of the neighbouring nuclei with the young cyst nucleus can also be brought about, followed by the change in form of the large nucleus thus formed. Another important case in which the loss of water in the nucleus might play a part is the change of nuclear size in the young parenchyma cells. We know, for example, that the cell nuclei, together with the nucleoli in the growing cells, which have stopped so as to divide, sometimes often grow and then diminish in size later (see Schiller on Antithamnion, 48, p. 285). Among other examples of nuclear changes which, according to Schiller's observation, depend in all probability on the physiological processes in the cell, are those of certain regenerated cells which result from injury. In each cell there may be several nuclei lying like a string of pearls, one after the other.

This observation resembles that of Neměc (36) in the plerome of Ricinus communis and $R$. borboniensis. Here these nuclei very often fuse together, and from such a mass only one large nucleus results, which may be divided again. These nuclei, which lie in a straight line like strings of pearls, have, according to Neměc, a nuclear mass in direct relation to the size of the cell (pp. I28-9). Neměc also puts forward another view, for he adds: 'Wir haben jedoch gesehen, dass Zellen, die mit gleicher Anzahl von Kernen versehen sind, eine beträchtliche Verschiedenheit in ihrer Grösse zeigen können, welcher Umstand mit der eben entwickelten Annahme nicht übereinzustimmen scheint. Aber erstens hängt die Kernteilung auch mit der in der Zelle enthaltenen Zytoplasmamasse zusammen. Zweitens, ist diese nicht einfach der Zellgrösse gleich, da die Pflanzenzellen zahlreiche Vakuolen enthalten, deren Grösse es bedingt, dass eine recht grosse Zelle weniger Zytoplasma enthalten kann, als eine andere ebenso grosse oder sogar kleinere ' (p. $\left.13^{6}\right)$. In other words, the size of the nucleus depends entirely on the age or the physiological conditions in and immediately around the cell.

Schiller stated that all forms of nuclei occur in Antithamnion cresc. var. tenuissima and $A$.plumula, although the cell form remains the same.

It also appears very clear from the observations of Kohl (20), Van Bambeke (64), Lidfors (27), and other investigators, that the nucleus possesses 
an active tendency to change its form, and I find this to be the case from my own observations. As stated, this does not depend on the cell form but only on the physiological processes there. This is demonstrated by the difference between the nuclear form of the common or raphid cell and those of its neighbouring cells which are without crystals and of the same size.

I agree with Schiller that the supposition of Miehe (35), Haberlandt (15), Rosen (43), and other investigators, that the nuclear forms are due to tension which is brought about by the change in cell form, is entirely wrong.

Smolak (49) writes about his observations in Prumus domestica, var. Victoria, with regard to the change in nuclear form in the palisade and spongy parenchyma cells, which were affected by the silver-leaf disease. He says on p. I45: "While the septum-like nuclei appear in the palisade cells rather frequently, yet this is not the case in the spongy parenchyma. On the contrary, in the latter tissue, the nuclei commonly show sharppointed lobes as above described. Probably the form which the disorganized nucleus takes may be dependent on the form of the cells.' On p. 150 the author further says: "The abnormal increase in size of the nucleus is-to judge by the manner of its occurrence-connected with the increase of metabolism, just as it is, for instance, in the large nuclei in the glands of animals or in healthy tissues of the seaweed Antithamnion (Schiller, 14), where the surface of the nuclei is much increased in size by enlargement and change of form or development of lobes.'

I agree with Smolak that the increase in size or very often the change in form may be connected with the increase of metabolism. The change in nuclear form, as it is demonstrated by his figures, shows that it is not due to the increase of metabolism, but to pathological phenomena which are no doubt caused by toxaemia.

In his first paragraph he contradicts himself by assuming that in an organized cell the changes in nuclear form are dependent on the cellular form, but I believe that it has no relation to cell form. On the contrary, it is influenced by the metabolic processes either physiological or pathological therein.

The behaviour of the contents of the raphid cell nucleus with respect to the nucleolus leads to the supposition of water loss. The more water the nucleus is deprived of, the larger becomes the nucleolus, which is to be regarded as nothing more than a secretion of the nucleus, that is to say, a metabolic product.

The nucleoli appear especially large in the hypertrophied crystal cells, whereas, as previously stated, they do not assume any unduly large proportions nor become very conspicuous in the nucleus of a normal parenchyma cell. Because of this abnormal nucleolar size in such hypertrophied crystal cells very often there results, in all probability, a special process in the 
pathological cell. For example, the nucleolar proteins might change into secretion products.

According to Haecker's (16) theory of the structure of the nucleus, the nucleolus is merely a splitting off or intermediate product due to the change in material. These products are removed from the nuclear content as a sort of secretion during the rest period at the beginning of mitosis, and may be either in combined or uncombined form. Haecker therefore concludes : 'Inasmuch as the need for living substance increases when division becomes more active, as a necessary consequence there follows the production of living substance in the form of large and-because of the small size of the nucleus-compact nucleoli.' The opinion of Haecker that the nucleoli are living substances is, however, contradictory to his assumption that they are cleavage products or secretions.

Other important evidences of the secretory-like character of the nucleolus are that the nucleolar substance increases considerably as soon as the nucleus is affected by the abnormal concentration of acidity in the hypertrophied cyst cell, and also the appearance of the death and dissolution of the nucleus, which is very striking as soon as the nucleolus has filled the entire volume of the nucleus.

Although the abnormal increase in size of the nucleolus gives us some information as to the end of its existence, the opinion is that its contents are nothing but an assimilation or secretion product. This also finds support in the abnormal size of the nucleolus in the primary endosperm nucleus, which I have occasionally observed in the embryo-sac of Gunnera shortly before division (see 40, Plate IV, Fig. 28). But inasmuch as we have to deal in the latter with a normal or regular phenomenon and the division of the nucleus directly follows the increase in size of the nucleolus, one should make a distinction between the two.

After this discussion of the rôle of the nucleolus in the hypertrophied cyst nucleus we may accept the theory of Haecker with the proviso that the nucleolus is not regarded in pathological cases as an intermediate but as an end product of the metabolism; his theory deals exclusively with an excretion of the nucleolar substance during the division of the nucleus under normal conditions.

Other cytologists, like Carlier (2) and Heidenhain (17), believe that the nucleolus is nothing more than an organized excretion product of nuclear metabolism, and that this substance should be separated from the chromatin.

Wilson (60) agrees with Haecker that the nucleoli may be regarded as a transformation product of the chromatin or as a chemical cleavage product or secretion. Wilson says: "It seems not improbable that nucleoli are tributary to the same general process, perhaps serving as storehouses of material formed incidentally to the general nuclear activity, but not 
of further direct use.' The expression 'storehouses' certainly gives the impression that the nucleolus contains reserve products, which are stored in them to be used later for a specific purpose.

Carnoy and Le Brun $(4,5,6)$ stated, as a result of their investigations on the germinal vesicle of Amphibia, that the nucleoli represent products from which the chromosomes are derived.

Botanists, more especially Zimmermann (67), Reinke, ${ }^{1}$ Went, ${ }^{1}$ Farmer, ${ }^{1}$ also O. Hertwig ${ }^{1}$ and others, agree to this view-point. Strasburger and his school, who were at first of the opinion that the nucleolus is used especially as construction material for spindles, accepted later the dominating theory at that time, that the nucleolus is of importance as the source of chromatin. Although the authors mentioned observe the superposition and the approximation of the nucleolus to the chromatin substance, particularly in the spireme stage, other investigators were able to determine its position along the nuclear wall and separated from the chromatin substance.

Schürhoff (57), who adheres to the theory that the chromatin is derived from the nucleolus, says on p. $5^{6}$ of his paper: 'Das Stadium der Synapsis ist nun dadurch ausgezeichnet, dass sich die Gesamtheit aller fädigen Elemente des Kerns dem Kernkörperchen anlegt. Wenn wir hier von den verschiedenen Theorien, die sich auf die Wechselwirkungen der einzelnen Chromosomen beziehen, absehen wollen, so lässt sich andererseits nicht in Abrede stellen, dass es in diesem Stadium zu lebhaften Beziehungen der künftigen Chromosomen zu dem Kernkörperchen kommt.' On p. 57 of his paper, however, he says regarding the behaviour of nucleoles during synapsis in the embryo-sac mother-cell of Lilium Martagon: 'Allerdings beobachten wir im Stadium der Synapsis regelmässig, dass das Kernkörperchen der Kernwand direkt anliegt, so dass während dieses Stadiums ein Auftreten von nucleolar Substanz nicht ausgeschlossen wäre, doch finden sich im umgebenden Zytoplasma keine Anzeichen für eine derartige Abgabe von Substanz.' In this Schürhoff contradicts himself. Between the chromatin substance and the nucleoles of the nuclei of the connective tissue of the pollen sac of Arum maculatum, he observed threads which join them and which after staining take the same colour as the chromatin, according to the statement on p. 63 of the same paper. As soon as the chromatin increases its staining power the nucleolus loses its intensive colour. On account of these two observations I believe that the threads are nothing more than chromatin formed from the substance of the nucleoli.

Even though the staining of the nuclear material is the same as the chromatin, it is very difficult to accept Schürhoff's opinion that both are the same chemical substance. It may be possible that the threads are 
formed to facilitate the transmission of secondary substance resulting from the activity of chromatin substance.

On the other hand, one finds no reason to regard the difference in staining between the nucleoles and the nucleus as evidence for Schürhoff's view of the latter.

Contrary to the statements of botanists thus far mentioned, Van Wisselingh, in his recent paper on Zygnema cruciatum (62), says that the chromosomes arise from the nuclear network and not from the nucleoles (p. Io).

Arthur Meyer (33 and 34) regards the nucleoles as a part of the nucleus, consisting of protein substances which resemble the nucleo-proteins and which belong, probably, to a special chemical group.

Regarding the latest view-point among the zoologists, it is worth while to refer to the publications and discussions of Schreiner (52-4) and Hogben (18).

Schreiner mentioned an excretion of particles through the nuclear wall by way of the nucleolar threads in the fat cells of Myxine, thus giving rise to stainable plasm rods. This author, referring to his own results, says on p. 138 : 'Diese Untersuchungen haben als Resultat ergeben, dass das häufige Auftreten von feinen Plasmakörnchen in der unmittelbaren Nähe innerhalb der Kernmembran von der Nukleolarsubstanz herstammt.' Schreiner believes that these granular bodies or fuchsinophil plasma elements are active in the process of excretion, and that the fat substance is indirectly formed from the nucleolus.

Hogben (p. 286), Loyez, and Hegner (see Hogben) stated that the secondary nuclei originate from the granules which have been ejected from the nucleus of the oocyte nurse cells and oocyte follicles and transferred as chromidia into nucleoform bodies by the cytoplasm of the egg. 'He finally regards the nucleoles as transitory structures.

Schiller (47) agrees with Haecker, and adds: "The nucleoli are still separated in soluble form from the nucleus during the inactive period of the latter as a kind of secretion at the beginning of the mitosis.' He also believes that the increase of nuclear substance, i. e. division, depends upon favourable external conditions.

Regarding the division I agree entirely with him, but not in regard to the increase under certain circumstances, as in the cyst cells in the parenchyma tissue of Anthurium. It is a fact that in pathological cases the nucleolus becomes larger with every following division. In this case, no doubt, the influence of abnormal conditions are of importance.

Zacharias (66) stated that the advanced age of the leaves of Galanthus occurs together with the decrease of the nucleolar substance of the nucleoli. This statement may hold true so far as it concerns Galanthus, but not always in other cases. Changes in form and size of nucleus and nucleolus are very different, according to the nature of the pathological circumstances. 
At the end of this discussion of the behaviour of the nucleus and nucleolus we may come finally to the conclusion that the abnormal change in form of the nucleus depends directly upon water loss. Perhaps also short intervals of pressure, which may occur in the cell as the result of purely mechanical or physico-chemical causes, may play a part, as may also abnormal acidity, which in turn may be caused by infection. The specific normal behaviour of the nucleolus indicates, after all, that the latter is undoubtedly only a final product of metabolism.

\section{The Behaviour of the Protoplasm.}

We come now to the second point of our discussion, or the behaviour of the protoplasm during the development of crystal cells. This behaviour, especially in an ordinary raphid cell, has not as yet been made the subject of a special study.

As a result of observations we know of course that as soon as the calcium oxalate appears in the vacuoles the normal movement or activity of the protoplasm is disturbed, which is no doubt the cause of the lateral position of the nucleus. As already stated, the young cysts are characterized by their extraordinary density of protoplasm, in which numerous vacuoles gradually a ppear, instead of the large one which is usually observed in normal raphid cells. These vacuoles then fuse into one large vacuole in which crystal colonies are developed. The concentrated mass of protoplasm which appears so conspicuously in the young cysts reminds one of that of a large embryo-sac cell with its much smaller protoplasmic content. It clearly indicates an infected or pathological tissue. This abnormal accumulation of protoplasm may perhaps be explained by assuming that during or before the fusion of two protoplasts a concentration of the protoplasmic mass is effected, the cause of which is as yet unknown.

This concentration of protoplasm may be caused by the calcium oxalate which is present in liquid form and concentrated there as a result of the accumulation of that substance from a number of neighbouring cells by endosmosis, or through some other chemical or physico-chemical process which has previously taken place.

However, it is unquestionable that the extraordinary concentration existing in two adjacent protoplasts constitutes evidence of a high degree of acidity in the protoplasm of these cells, inasmuch as there is no question here of embryonic tissue or of endosperm cells.

It is not a question of wall dissolution, as has been observed in pathological cases, but of their bursting. This may perhaps be caused by a too great osmotic pressure. Irregular physiological processes take place in a certain cell complex which probably lead to the bursting. Whether or not these processes have their origin in abnormal external 
conditions remains unknown. In a normal raphid cell we do not find such plasma concentrations as we found in the young cyst cells, and usually only one central vacuole filled with mucilage is developed where the raphid colony is gradually formed.

\section{The Formation of the Crystal Colonies.}

In Anthurium the wall of the polyhedric crystals and that of each raphid crystal serves as a plasma wall, and is in all probability of hemicellulose. This can be easily tested on sections treated for. some time with a ferric ammonium sulphate solution, by which the crystals are dissolved.

In normal cells the presence of the cellulose wall around the crystal colonies probably means that it serves as an enlargement of the inside surface of the cell, an enlargement which has obvious physiological significance. On account of the separation of the crystal complex from the living part of the protoplast, the surface of the latter becomes larger, thus serving as a protection to that part of the cell which has not been affected. As a result of the irregular processes, we observe in the crystal cells an accumulation of the crystal substance in the form of raphid colonies near, beside, or behind one another.

The first investigator who studied Anthurium in relation to the formation of calcium oxalate in the parenchymatous tissue of the perianth leaf was Kohl (21). He made the statement that, owing to the insufficient assimilation in the cells of that organ, and also because the conflicting influence of salts which are formed later is excluded, primary calcium oxalate crystals are only to be found, while the secondary and tertiary are dependent on the influence of light, and are consequently formed in other parts of the plant. According to Kohl the primary crystals usually in raphid form are in tubes, which are for the most part parallel to the main axis of the petals. Furthermore, Kohl studied some plants among the Aroideae, where primary crystals occur in the form of polyhedric crystals. The author therefore studied both the cells containing the polyhedric and those containing monoclinic crystals.

Inasmuch as Kohl did not study the history of the development of the crystal cells in Anthurium, and was content only to make a statement of the crystal types formed in this plant, it was important to make a thorough study of it.

As he states, the petals of the flower are the best available material for this purpose, and I decided, therefore, to make a special effort to study those parts of the plant very carefully. However, no difference could be observed between the form of the calcium oxalate crystals in the petals and those of the leaves, stem, and roots. 
Furthermore, the so-called crystal tubes (Kristallschläuche) of Kohl are not tubes at all, but are hypertrophied cells which are formed in the parenchymatous tissue after the fusion of a number of cells of a certain cell complex. They have not the form of tubes only, as Kohl contends, but they are round, oval, or curved, according to the position of the cells.

Having studied the developmental history of the crystal cysts, I have decided to make a careful study of other so-called Kristallschläuche described by Kohl and others, and shall not be surprised to observe the same phenomena.

According to Dalitsch's study on the leaf anatomy in the Aroideae, the raphids are formed in those cells which lie vertically on each other. Such cells are fused together, and the crystals are embedded in a dense mass of protoplasm. Dalitsch (p. 345) observed this in Philodendron longilaminatum.

In Fig. I3, Plate III of his paper (8) the author demonstrates a case of several raphid colonies in a parenchyma cell near the epidermis of the leaf.

Recently a similar case has been described by Porsch. Engler(12), who mentioned Porsch as the author of the crystal cells in Philodendron Sellowii, did not give the title or the year of issue for that particular publication (p. 28). Probably neither Dalitsch nor Porsch saw any nuclear fusion, and did not carefully study the development of the crystal cysts, but, with Hansteen, regarded the fused cells as crystal tubes.

The crystal colonies in $A$. scandens and $A$. Scherzerianum are not in a common sac, as with those found in the regular raphid cells just discussed. Besides this distinction, every needle is separated from the plasma by a plasma and not a cellulose wall.

The solution of the cell wall in pathological cells is of course the cause of the formation of a number of crystal colonies in a single crystal cell, and probably the cause of their position, because the pressure of the protoplasm of the neighbouring protoplasts acts doubtless in different directions, whereas the fusions of the protoplasts do not all take place at the same time. The result is that here we are concerned principally with abnormal regulatory phenomena located in certain cell regions of the tissue.

On the piercing of the cell wall between two or three contiguous parenchyma cells, cell fusion takes place, and the calcium oxalate, together with the plasma substance, is forced near to the fusion point of the nuclei, the position at which the first crystal colony is to be formed.

It is highly probable that the union takes place in the immediate vicinity of the break in the cell wall or possibly at the opposite side of the break in the wall. Immediately after the union it may be that, in the first case, the two nuclei are carried along in the direction of the plasma movement, after which they fuse together. The first colony which appears indi- 
cates the direction of the plasma pressure and the direction of concentration of the calcium oxalate.

A fact which serves as a logical argument is the striking peculiarity that, while the extreme outside parenchyma cell rows contain less water and consequently show mostly polyhedric crystals, the inside cell tissues contain more water, and therefore show monoclinic crystals.

There are formed, therefore, two rings which resemble those of Liesegang (29-31). This striking relation between these different crystal regions and the colloid theory of Liesegang can be observed in other cases, i. e. in two neighbouring cells with calcium oxalate crystals of different forms. This phenomenon is very common in nearly any plant tissue. Although an indirect application of the theory of Liesegang is possible in these cases of different crystal formations in the parenchymatous tissue, there is not yet sufficient material at hand to make a suggestion for a direct relationship between the colloidal theory and the cell fusion before the crystal formation.

The formation of calcium oxalate crystal cysts, whereby large cell complexes of the parenchymatous tissue are destroyed, must eventually have an effect on the physical appearance of the plant. Although such has not yet been observed, it is certain that the plant will show some effect as soon as the normal function of the vesicular elements are disturbed by the increase in the formation of the cysts.

\section{SUMMARY.}

After having studied the crystal cysts of the genus Anthurium, the following final statements can be made:

I. Two different crystal regions separated from each other exist in the parenchymatous tissue of the perianth leaves of Antfurium scandens and A. Scherzerianum, of which the outside region consists of polyhedric crystals, while the inside is characterized by monoclinic raphid crystals with more water than the former.

2. The region of the monoclinic crystals is further distinguished from the other where polyhedric crystals occur, in that in the former fusion of cells and their nuclei occurs and precedes the crystal formation, while in the latter no fusion takes place.

3. Symplasts are formed as a result of cell and nuclear fusion, whereby often the whole parenchymatous tissue of the organ is dissolved.

4. The formation of the symplasts consists mainly in the gradual increase in the density of the protoplasm of two neighbouring cells and the subsequent hypertrophy of their nuclei. The latter assume positions on opposite sides of a common cell wall. After this cell wall has been broken 
through by the increased physical pressure in one or both of the cells, the fusion of the nuclei takes place.

5. The large nucleus resulting from the fusion of these nuclei keeps its more or less round form as long as it shows a tendency towards fusion. It may be amoeboid, spiral, and lobed, and takes up a position along the cell wall, and very often at one end of the hypertrophied cell.

6. During the fusion of the nuclei several calcium oxalate crystal colonies are formed in different positions immediately around the hypertrophied nucleus.

7. At the end of the crystal formation in the symplast the nucleus takes a prolonged or oval form, while the nucleolus enlarges considerably, the nucleus becoming thereby homogeneous. Finally, the hypertrophied nucleus dissolves and the crystal colonies remain in the cyst cell or symplast.

8. From the latter it appears clear that the behaviour of the nucleus, i. e. the cell and nuclear fusion, is in relation to the separation of the different crystal regions.

9. It appears also, from the increase in size of the nucleolus at the end of the struggle for existence by the nucleus of the symplast, that the nucleolus is only an end product of metabolism.

IO. The formation of these symplasts is an extraordinary pathological phenomenon; it is the first case known in which the formation of calcium oxalate crystal colonies is accompanied by cell and nuclear fusion.

In conclusion, I wish to extend my thanks to Drs. N. Kopeloff, H. C. Sands, and Henry Keller for their friendly help in preparing this paper for publication.

\section{EXPLANATION OF FIGURES IN PLATE II.}

Illustrating Dr. Samuels's paper on Anthurium.

The drawings were made with an Abbe apparatus from sections of the affected parenchymatous tissue taken from the perianth leaf of Anthurium Scherzerianum.

Fig. I. Beginning of the formation of the hypertrophied cell which may be distinguished from neighbouring cells by the extraordinary content of plasma and the size of the nucleus immediately following the fusion process. Oil immersion, ocular 8 .

Fig. 2. The fusion of several nuclei in a young cyst. Oil immersion, ocular 8 .

Fig. 3. The fusion of two large cyst nuclei lying in a plasma ring. Oil immersion, ocular 12.

Fig. 4. The union of two large cyst nuclei which are lying in a plasma ring. Oil immersion, ocular 12 . 
Fig. 5. Young symplast in the central part of the perigone leaf. Nuclei after the fusion lying in an extraordinarily large protoplasmic mass, and moved more or less to the one extremity of the cell. Oil immersion, ocular 8.

Fig. 6. Symplast from the second layer of the parenchymatous tissue. Nucleus at the side wall of the cell. Raphid colony with curved crystals. Oil immersion, ocular 8.

Fig. 7. Symplast with nucleus at one of the poles of the cell, connected by plasma threads with the protoplasm wall, and situated in a dense mass of protoplasm. Oil immersion, ocular 4.

Fig. 8. A cyst in the parenchymatous tissue of a perigone leaf. Fusion of a cyst with a neighbouring cell and the fusion of their nuclei. The cyst occurs as a space in the tissue. Crystal colonies developed in different positions. Oil immersion, ocular 8.

Fig. 9. Cyst from the central part of the perigone, with the form of an embryo-sac and with protoplasm threads in the cell. Two nuclei united, i. e. lobed nuclei, lying along the side wall. Crystal colonies in more or less different positions. Oil immersion, ocular 8.

Fig. Iо. Cyst nucleus in lobed form. Oil immersion, ocular I2.

Fig. Ir. Fusion and union of a symplast nucleus with other nuclei in the parenchymatous tissue. Crystal substance already formed. Oil immersion, ocular i 2 .

Fig. I2. Shell-formed symplast nucleus from the parenchymatous tissue. Oil immersion, ocular I2.

Fig. I3. Lobed cyst nucleus lying at the side wall of a parenchymatous cell of the perigone leaf. Oil immersion, ocular $\mathrm{I} 2$.

Fig. I4. Cyst nucleus with spiral form and lying along the side wall of the cell of the same tissue. Oil immersion, ocular $\mathbf{2} 2$.

Fig. 15. Spherical cyst nucleus stretched out and lying along the side wall in the protoplasm mass of a cell of the anther tissue. Oil immersion, ocular 7 .

Fig. I6. Nucleus of a symplast stretched out and lying along the side wall of a parenchymatous cell with newly formed raphides. The nucleolus has grown extraordinarily. Oil immersion, ocular 12 .

\section{LITERATURE CITED.}

1. Bally (1912): Cytologische Studien an Chytridineen. Jahrbücher für wiss. Botanik, vol. 1, p. 95.

2. Carlier, E. Wace (1899): Secretion: a Chapter in Cell-physiology. Birmingham.

3. CARnoy, J. B. (1884): La biologie cellulaire. Liège.

4. — et Lebrun (1897): La citodiérèse de l'œuf. La Cellule.

5. $(1898)$ :

6. $\longrightarrow(1899)$ :

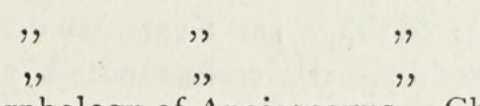

7. Coulter and Chamberlain (1907): Morphology of Angiosperms. Chicago.

8. Dalitsch (1886): Beiträge zur Kenntniss der Blattanatomie der Aroideae. Botanisches Centralblatt, vol. xxi-xxvi.

9. DE BARY, A. (1877): Vergleichende Anatomie der vegetativen Organe der Phanerogamen und Farne. Strassburg.

10. De la Rue (1869): Ueber Krystalldrüsen bei einigen Pflanzen. Botanische Zeitung, pp. 537-9.

11. Derschau, M. v. (1915): Der Austritt ungelöster Substanz aus dem Zellkern. Archiv f. Zellforschung, vol. xiv.

12. Engler (1915): Pflanzenfamilien, iv. Ergänzungsheft iii, p. 28.

13. Fuchs, P. C. A. (1898): Untersuchungen über den Bau der Raphidenzellen. Oesterr. Bot. Zeitung, pp. 537-9.

14. Gutenberg, H. K. v. (1909): Cytologische Studien an Synchytrium-Gallen. Jahrb. f. wiss. Botanik, vol. xlvi.

15. Haberlandt, G. (1887): Ueber die Beziehungen zwischen Funktion und Lage der Zellkerne. Jena.

16. Haecker, V. (1899): Praxis und Theorie der Zellen- und Befruchtungslehre, p. ir6. Jena. 
17. Heidenhain, Martin (1907): Plasma und Zelle. Jena.

18. Hogben, L. (1920): Studies on Synapsis, I and II. Proceedings of the Royal Society, London, Series B, vol. xci, p. 268 , and p. 305 .

19. Johow, F. (1880): Untersuchungen über die Zellkerne in den Secretbehältern und Parenchymzellen der höheren Monocotylen, pp. 9-2 I.

20. KонL, F. G. (1889): Anatomisch-physiologische Untersuchungen über die Kalksalze und Kieselsäure in der Pflanze. Marburg.

21. (1897): Zur Physiologie des Zellkernes. Bot. Centralblatt, vol. lxxii, pp. I68-9.

22. (1899): Untersuchungen über die Raphidenzellen. Ibid., vol. lxxix, pp. 273-8I.

23. Koernicke (1913): Der heutige Stand der pflanzlichen Zellforschung. Ber. d. Deutschen Bot. Gesellschaft.

24. Korschelt, E. (1891): Beiträge zur Morphologie und Physiologie des Zellkernes. Zool. Jahrbiicher, Abt. für Anatomie und Ontogenie der Tiere, vol. iv, pp. I-I54.

25. KüSter, ERNST (1916): Pathologische Pflanzen-Anatomie. Jena.

26. Kusano (1907): On the Cytology of Synchytrium. Centralblatt für Bacteriologie, vol.ii, p. $53^{3}$.

27. Lidfors, B. (1908): Ueber kinoplasmatische Verbindungsfäden zwischen Zellkernen und Chromatophoren. Lunds Universitäts-Årsskrift, N. F., Afd. 2, vol. iv, No. I.

28. (1908): Kongl. fysiogr. Selskapets-Handl., N. F., Bd. lix, No. I.

29. Liesegang, R. E. (1898): Über chemische Reaktionen und Gallerten. Düsseldorf.

30. (1907): Über die Schichtungen bei Diffusionen.

31. (1907): Über die scheinbare Reaktions-Verzögerung durch Gelatine. Düsseldorf.

32. Magnus, W. (1900): Studien an der endotrophen Mykorhiza. Jahrb. für wiss. Botanik, vol. xxxv.

33. Meyer, Arthur (1917): Die biologische Bedeutung der Nukleolen. Ber. d. Deutschen Bot. Gesellschaft, xxxv.

34. - (1918): Die biologische Bedeutung der Nukleolen. Zool. Anzeiger, vol. xlix.

35. Miene, H. (1899): Histologische und experimentelle Untersuchungen über die Anlage der Spaltöffnungen einiger Monokotylen. Bot. Centralblatt, vol. lxxviii, p. $3^{86 .}$

36. NemĚc, B. (1910): Das Problem der Befruchtungsvorgänge und andere zytologische Fragen. Berlin.

37. (1911): Über die Nematodenkrankheit der Zuckerrübe. Zeitschrift für Pflanzenkrankheiten, vol. xxi, p. I.

38. Nussbaum, M. (1877): Ueber den Bau und die Tätigkeit der Drüsen, Part I. Archiv f. mikrosk. Anatomie, vol. xiii.

39. (1878): Part II. Ibid., vol. xv.

40. (1879): Part III. Ibid., vol. xvi.

41. (1882): Part IV. Ibid., vol. xxi.

42. Rosanoff, S. (1867): Ueber Krystalldrüsen in den Pflanzen. Botanische Zeitung, p. 4I.

43. Rosen, F. (1892): Beiträge zur Kenntniss der Pflanzenzellen. I. Ueber tinktionelle Unterscheidung verschiedener Kernbestandteile und der Sexualkerne. Cohn's Beiträge, vol. vi.

44. - (1895): Part II. Ibid., vol. vii.

45. Samuels, J. A. (1912): Étude sur le développement du sac embryonnaire et de la fécondation du Gunnera macrophylla Bl. Archiv für Zellforschung, pp. 52-1 20.

46. (1913): Etude cytologique sur les relations existant entre le noyau et le développe ment des cristaux d'oxalate de chaux dans les cellules parenchymateuses du périanthe d'Anthurium. Comptes rendus, Paris, pp. I $275^{-7}$.

47. Schiller, J. (1908): Die Bedeutung des Zellkernes, etc. Jahresber. d. k. k. Staatsrealschule in Triest.

48. (1911): Die Kerne von Antithamnion. Jahrb. für wiss. Bot., vol. xlix.

49. Smolak, A. (1915): A Contribution to our Knowledge of Silver-leaf Disease. Annals of Applied Biology, vol. ii, pp. I38-57.

50. Schniewind-Thies, J. (1897): Beiträge zur Kenntniss der Septalnektarien. Jena.

51. Schwarz, F. (1884): Beiträge zur Entwickelungsgeschichte des pflanzlichen Zellkernes nach der Teilung, Part I. Beiträge zur Biologie der Pflanzen, vol. iv.

52. Schreiner, K. E. (1915): Ueber Kern- und Plasmaveränderungen in Fettzellen während des Fettansatzes. Anat. Anzeiger, vol. xlviii, pp. I45-7r. 
53. Schreiner, K. E. (1917): Zur Kenntniss der Zellgranula, Part I. Arch. f. mikrosk. Anatomie, vol. lxxxix, pp. 79-188.

54. (1919) : Zur Kenntniss der Zellgranula, Part II. Ibid., vol. xcii, pp. I-63.

55. Strasburger, E. (1909) : Zeitpunkt der Bestimmung des Geschlechts, Apogamie, Parthenogenesis und Reduktionsteilung. Histologische Beiträge, Heft 7 .

56. (1908): Chromosomenzahlen, \&c. Jahrb. f. wiss. Botanik, vol. xlv.

57. Schurhoff, P. N. (1918): Die Beziehungen des Kernkörperchens zu den Chromosomen und Spindelfasern. Flora, vol. cxi, pp. 52-66.

58. Tischler, G. (1908): Zellstudien an sterilen Bastardpflanzen. Archiv f. Zellforschung, vol. i.

59. Wakker, J. H. (1886): De vorming der kristallen van kalkoxalaat in de plantencel. Maandblad voor Natuurwetenschappen, No. 7 .

60. Wilson, E. B. (1904): The Cell in Development and Inheritance. New York.

61. Winkler, H. (1906): Botanische Untersuchungen aus Buitenzorg. Ann. du Jardin botanique de Buitenzorg, vol. ii.

62. Wisselingh, C. v. (1914): On the Nucleolus and Karyokinesis in Zygnema. Rec. Trav. Bot. Néerlandais, xi.

63. Woycicki (1907): Ueber den Bau des Embryosackes bei Tropaeolum majus, L. Bulletin Acad. Cracovie.

64. Van Bambeke, Ch. (1886): Des formations artificielles du noyau. Arch. d. 1. Biologie, vol. vii.

65. Zacharias, E. (1885): Ueber den Nucleolus. Bot. Zeitung, p. 257.

66. (1895): Ueber das Verhalten des Zellkernes im wachsenden Gewebe. Flora, vol. lxxi.

67. Zimmermann (1892): Ueber das Verhalten der Nukleolen während der Karyokinese, Part I. Beiträge zur Morphologie und Physiologie der Pflanzenzelle, vol. xlix. 
Annals of Botany,
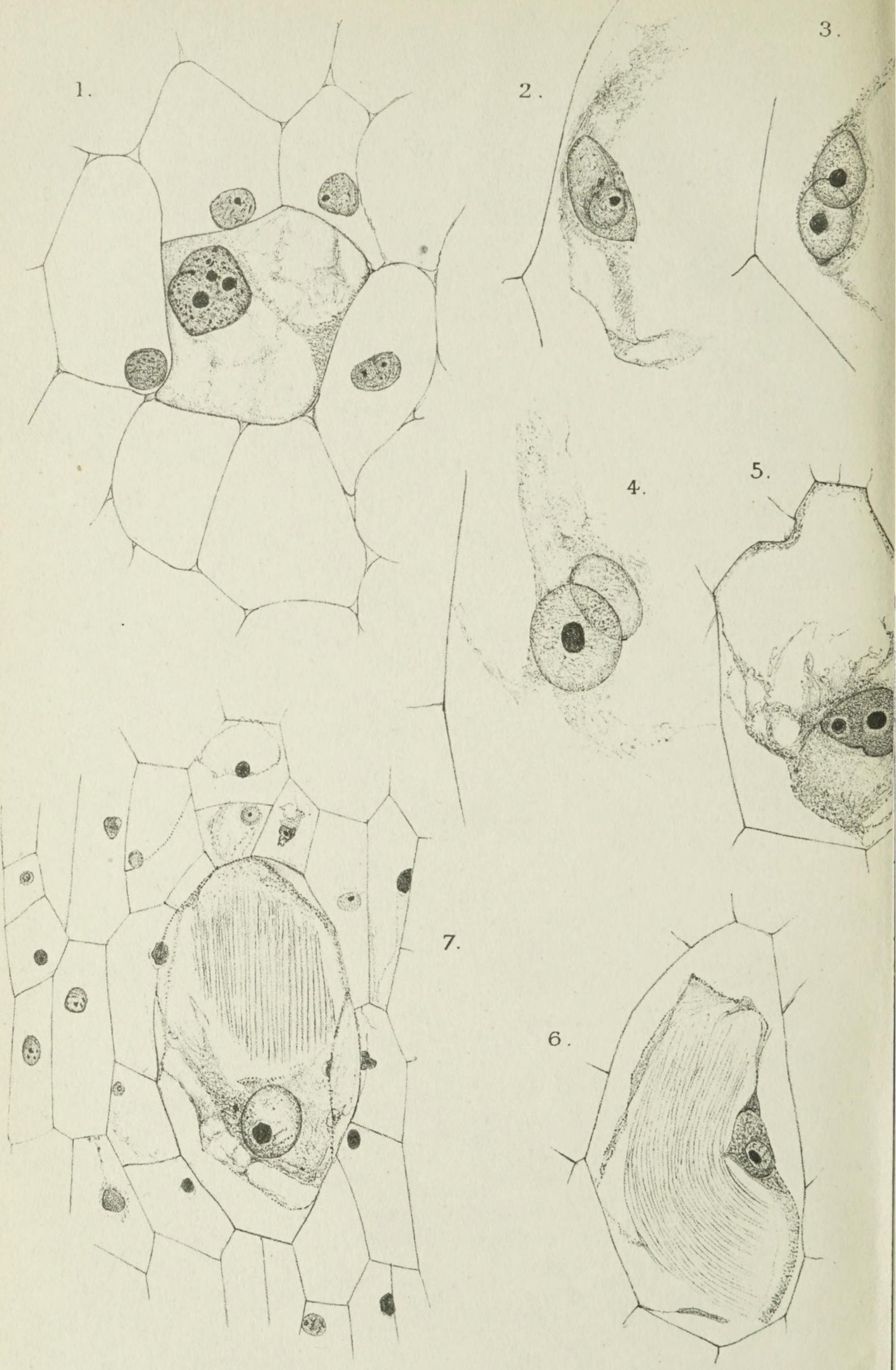

SAMUELS - CRYSTAL CYST FORMATION. 
Vol. XXXVII,PL.II.
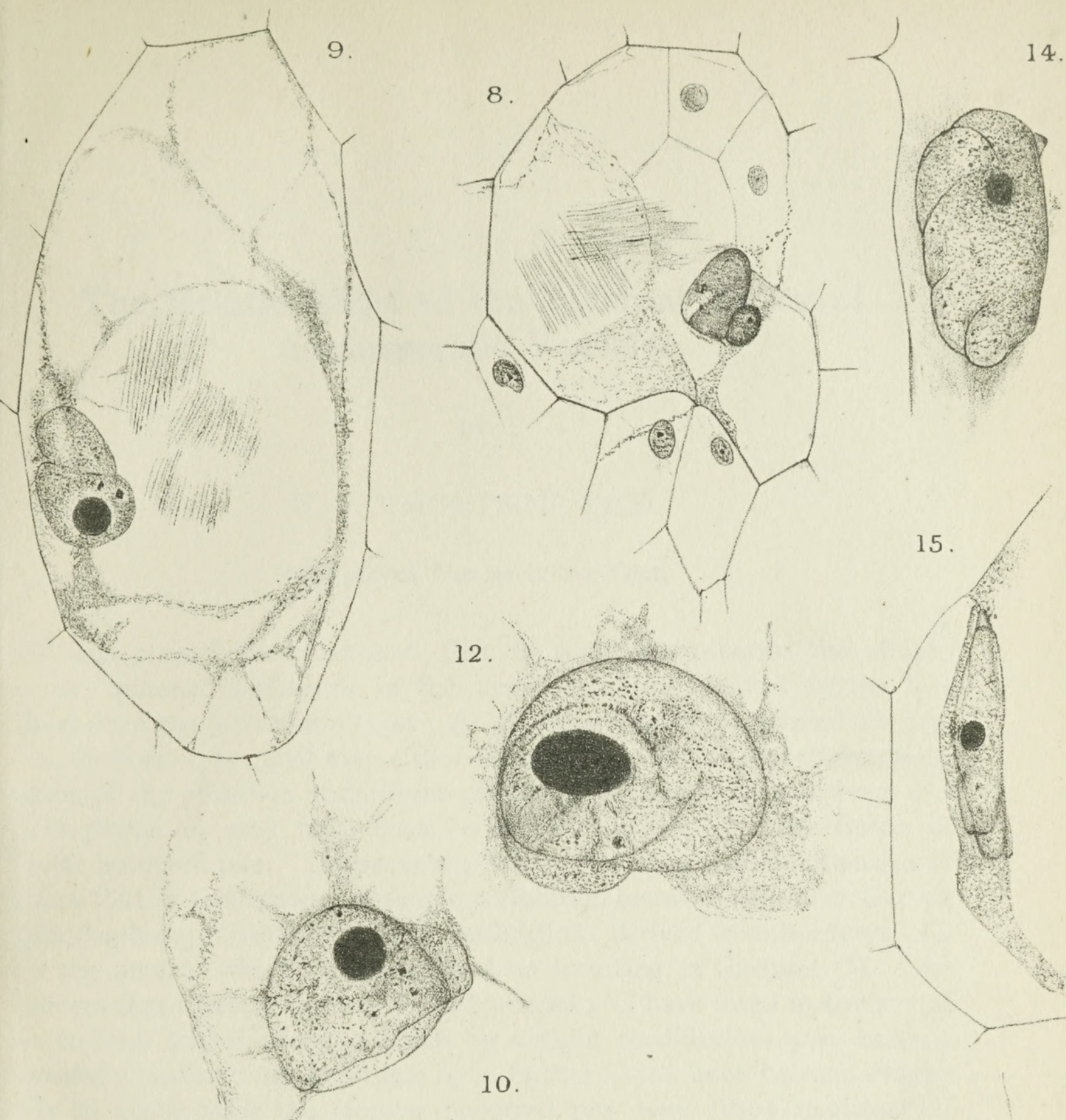

15.

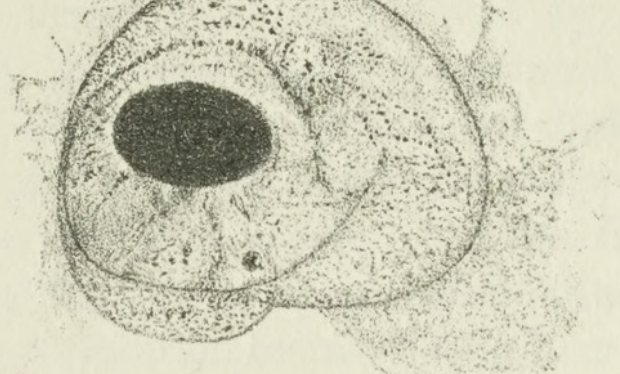

13.

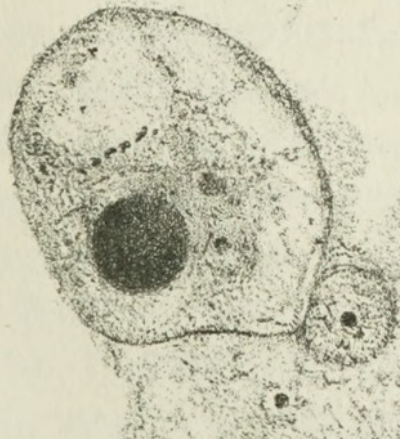

11.
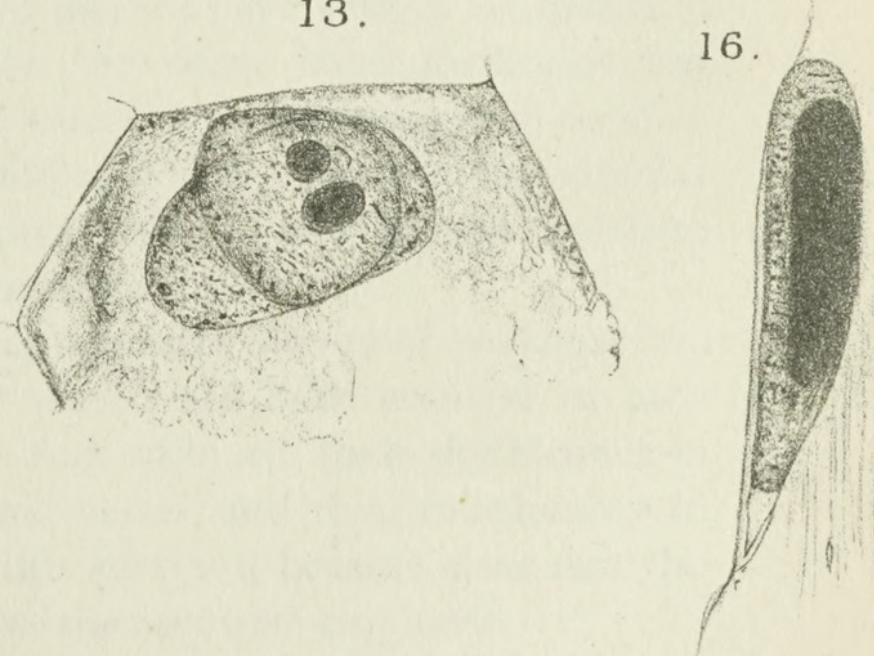

Hulth lith. et.imp 


\section{$2 \mathrm{BHL}$ Biodiversity Heritage Library}

Samuels, J. A. 1923. "A pathological anatomical study of crystal cyst formation in parenchymatous tissue in the genus Anthurium." Annals of botany 37, 159-181. https://doi.org/10.1093/oxfordjournals.aob.a089840.

View This Item Online: https://www.biodiversitylibrary.org/item/270686

DOI: https://doi.org/10.1093/oxfordjournals.aob.a089840

Permalink: https://www.biodiversitylibrary.org/partpdf/319077

\section{Holding Institution}

New York Botanical Garden, LuEsther T. Mertz Library

\section{Sponsored by}

BHL-SIL-FEDLINK

\section{Copyright \& Reuse}

Copyright Status: Public domain. The BHL considers that this work is no longer under copyright protection.

This document was created from content at the Biodiversity Heritage Library, the world's largest open access digital library for biodiversity literature and archives. Visit BHL at https://www.biodiversitylibrary.org. 